Черкун М.П., Катеренчук І.П.

\title{
Інформованість міських і сільських жителів про фактори ризику гіпертонічної хвороби як передумова прихильності до лікувально-профілактичних заходів
}

\author{
Українська медична стоматологічна академія, м. Полтава, Україна
}

ikaterenchuk@ukr.net

\author{
Черкун М.П., Катеренчук И.П. \\ Информированность городских и сельских жителей \\ о факторах риска гипертонической болезни \\ как предпосылка приверженности \\ к лечебно-профилактическим мероприятиям \\ Украинская медицинская стоматологическая академия, \\ г. Полтава, Украина
}

Cherkun M.P., Katerenchuk I.P.

Awareness of urban and rural inhabitants

about to hypertension risk factors as a prerequisition

for better compliance to therapeutic

and preventive measures

Ukrainian Medical Stomatological Academy,

Poltava, Ukraine

\section{Вступ}

Згідно $з$ даними епідеміологічних досліджень, що проводились на території України, гіпертонічна хвороба (ГХ) обумовлює високий рівень смертності населення України. Поширеність ГХ у міського та сільського населення України станом на 2010 рік становила 29,6 \% та $36,3 \%$, а досягнення цільових значень артеріального тиску (АТ) $15,0 \%$ та 8,0\% відповідно [1,6]. Всесвітньою організацією охорони здоров'я в 2013 році було затверджено стратегію профілактики хронічних неінфекційних захворювань на період 2013-2020 років. Основою даної стратегії стала резолюція ВООЗ № 66.10 щодо запобігання виникненню та прогресуванню серцевосудинних захворювань (СС3), шляхом впливу на фактори ризику (ФР) та розробка механізмів їх контролю (так звана «концепція факторів ризику»). Відомо, що основними коригованими факторами ризику, які стали головною метою даної стратегії ВОО3, є вживання алкоголю, паління, надлишкова маса тіла (та/або ожиріння), низький рівень фізичної активності, нездорове харчування $[2,6]$.

Прихильність до лікування - це ступінь відповідності поведінки хворого відносно рекомендацій, отриманих від лікаря у відношенні прийому препаратів, дотримання дієти та інших заходів щодо зміни стилю життя.

Прихильність до прийому лікарських препаратів це здатність пацієнта виконувати рекомендації лікаря у відношенні прийому препаратів та вживання лікарських засобів протягом невизначено тривалого часу [3]. Збільшення рівня прихильності до лікування шляхом підвищення інформованості сільського та міського населення щодо основних коригованих ФР залишається провідним завданням сьогодення, що забезпечує сприятливий прогноз результатів терапії. Неабиякої актуальності це завдання набуває у хворих на хронічні неінфекційні захворювання 3 коморбідним перебігом, лікування яких є тривалим і в переважній більшості випадків триває все життя [5]. Найбільш часто використовуваним опитувальником, за допомогою якого уже протягом останніх 40 років доволі успішно визначають рівень прихильності до лікування $\epsilon$ опитувальник Morisky-Green (MMAS-8) [9]. Згідно результатів тримісячного спостереження за лікуванням пацієнтів з артеріальною гіпертензією різних міст України в рамках програми «Можливості ефективного контролю артеріального тиску за допомогою вітчизняних ліків», до якого увійшло 10158 пацієнтів, було встановлено зворотну кореляційну залежність між прихильністю до лікування та наявністю коригованих факторів ризику ГХ. За встановленого низького та середнього рівня комплаєнтності, прослідковувалася тенденція до тютюнопаління, зловживання алкоголем $(\mathrm{P}<0,001)$, традиційного вживання солоної їжі та гіподинамії. Серед пацієнтів, які дотримувалися здорового способу життя, вживали щоденно свіжі овочі та фрукти, займалися фізичними вправами (5-6 разів на тиждень загальною тривалістю більше 10 годин на тиждень), мали вищу освіту та працювали визначався високий рівень прихильності до лікування, який асоціювався 3 досягненням цільових рівнів АТ [7,8]. Серед населення Полтавської області також прослідковується переважання низького та середнього рівня прихильності до корекції факторів ризику та медикаментозного лікування ГХ [4]. Цільовий рівень АТ (нижче 140/90 мм рт.ст. та 130/80 мм рт.ст. при наявності супутнього ЦД) визначається у $15,4 \%$ пацієнтів віком 40-60 років, тоді як науковці Свропейських країн та провідні наукові та лікувальні заклади України надають дані про досягнення цільового рівня АТ у 20\% хворих.

Мета дослідження - визначити значимість інформованості міських та сільських жителів Полтавської області про фактори ризику артеріальної гіпертензії та іiї 
вплив на прихильність до лікувально-профілактичних заходів, а також визначити переважання факторів ризику розвитку та прогресування гіпертонічної хвороби в залежності від територіальної приналежності пацієнтів.

\section{Матеріали та методи}

У дослідження включено 149 хворих віком від 22 до 85 років, які лікувалися на базі Полтавського обласного медичного клінічного кардіоваскулярного центру у період 3 січня 2019 року по лютий 2020 року. Жителів сільської місцевості було 66 чол. (44,0\%) та жителів міста - 83 чол. (56,0\%). Всі пацієнти були розподілені на 3 групи: перша - з ізольованим перебігом артеріальної гіпертензії; друга 3 поєднаним перебігом ГХ та ішемічної хвороби серця; третя група - 3 коморбідним перебігом ГХ, ішемічної хвороби серця (IXC) та цукровим діабетом (ЦД) 2 типу. Кожну з цих груп було поділено на 2 підгрупи в залежності від територіальної приналежності: жителі сільської та міської місцевості. До першої групи увійшло $43(28,9 \%)$ пацієнтів з ізольованим перебігом ГХ, серед яких чоловіків було 25 (58,0\%), жінок - 18 (42,0\%).

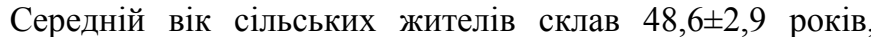
міських жителів 51,6 $\pm 2,6$ років. Частка сільських жителів даної групи склала 18 (41,8\%), міських - 25 (58,2\%). До другої групи включено 68 (45,6\%) пацієнтів 3 поєднаним перебігом ГX та IXC, серед яких чоловіків було 27 (39,7\%), жінок - 41 (60,3\%). Середній вік сільських пацієнтів даної групи склав $57 \pm 1,7$ років, міських пацієнтів - 58,4 $\pm 1,5$ років. Частка сільських жителів даної групи склала 34 (50,0\%), міських - 34 (50,0\%). Третю групу склали пацієнти з коморбідним перебігом ГХ, IXC та ЦД 2 типу - 38 (25,5\%), серед яких чоловіків було 18 (47,4\%), жінок - 20 (52,6\%). Частка сільських жителів даної групи склала $14(36,8 \%)$, міських - $24(63,2)$. Середній вік сільських пацієнтів склав $66,3 \pm 1,9$ років, міських $-67 \pm 1,7$ років.

Проаналізовано інформованість всіх пацієнтів щодо основних коригованих факторів ризику виникнення та прогресування ГХ. Рівень прихильності до прийому антигіпертензивних препаратів було оцінено шляхом використання опитувальника Моріски-Грін, що включав в себе 8 запитань (MMAS-8), кожне з яких відповідає 1 балу. Високий рівень прихильності присвоювався пацієнтам, котрі набрали 8 балів, середній рівень прихильності пацієнтам, що отримали 6-7 балів та низький рівень прихильності - пацієнтам, що набрали менше 6 балів [3]. Аналіз ефективності антигіпертензивної терапії визначався шляхом досягнення цільових значень АТ для кожної з порівнюваних груп. Встановлення зв'язку між інформованістю до факторів ризику, прихильністю до лікування та досягнення ефективного контролю було досягнуто за допомогою статистичної обробки даних програмою Microsoft Excel 2010 на базі MS Windows 10. Оцінка статистичної значущості результатів проводилася за методом $\left(\chi^{2}\right)$ Пірсона.

\section{Результати дослідження та їх обговорення}

Сільські жителі з ізольованим перебігом ГХ (група порівняння) виявились достатньо інформованими щодо основних коригованих факторів ризику виникнення та прогресування ГХ. Серед пацієнтів цієї групи показник інформованості сільських жителів склав 72,2\% випадків, серед міських жителів інформованість склала 80,0\%. Серед сільських жителів 3 поєднаним перебігом ГХ та ішемічної хвороби серця (IXC) інформованість склала відповідно серед сільських жителів 58,8\% та 85,3\% серед жителів міста. У групі з коморбідним перебігом ГХ з IXC та цукровим діабетом (ЦД) 2 типу інформованість серед сільських та міських жителів склала відповідно 57,1\% та $83,3 \%$. Порівняно висока інформованість сільських жителів з ізольованим перебігом ГХ ніж 3 коморбідним перебігом тісно пов'язана 3 віком пацієнтів. У першому випадку середній вік пацієнтів склав 48,6 $\pm 2,9$ років у другому $61,5 \pm 1,8$ років. Жителі міста кожної групи є більш інформованими щодо основних коригованих факторів ризику, ніж сільські жителі (p>0,005).

Найбільш поширеними основними коригованими факторами ризику ГХ серед сільської популяції $є$ : недотримання принципів здорового харчування(у 70,6\%), ожиріння (при чому переважно II-III ступеня) (у 54,4\%); серед міської популяції: зловживання алкоголем (у 47,1\%), надлишкова маса тіла (у 34,2\%) та низький рівень фізичної активності (у 47,1\%). Тютюнопаління в обох популяційних групах сягало 10,0\%, статистичної різниці не виявлено ( $\mathrm{p}>0,05)$.

Надлишкова маса тіла у контрольній групі сільського населення визначалася у 16,7\%, ожиріння у $77,8 \%$, зловживають алкоголем $38,9 \%$, мають низький рівень фізичної активності (заняття регулярною фізичною активністю менше 5-6 разів на тиждень) 29,9\%, не дотримувалися здорового харчування (щоденно не вживали свіжі овочі та фрукти, зловживали солоною їжею) 100\% пацієнтів. У аналогічній групі міського населення кориговані фактори ризику відзначались наступним чином: надмірна маса - 29,2\%, ожиріння - 45,8\%, зловживання алкоголем - 62,5\%, низький рівень фізичної активності - 39,2\%, не дотримувалися здорового харчування - 91,7\% хворих.

Серед сільських жителів 3 поєднаним перебігом ГХ та ішемічної хвороби серця (IXC) надлишкову масу мали 26,5\% пацієнтів, ожиріння - $61,8 \%$, зловживання алкоголем - 38,2\%, низьку фізичну активність - 31\%, нездорове харчування у 88,2\%. У жителів міста 3 такою ж патологією дані показники склали: надлишкова маса тіла $-44,1 \%$, ожиріння - 44,1\%, зловживали алкоголем $41,2 \%$, низька фізична активність - 44,2\%, нездорове харчування $85,3 \%$.

У групі з коморбідним перебігом ГХ з ІХC та ЦД 2 типу серед жителів сільської місцевості надлишкову масу мали 17,6\% пацієнтів, ожиріння - 23,5\%. У жителів міста $з$ такою ж патологією дані показники склали 29,2\% та $62,5 \%$ відповідно, при чому дана категорія пацієнтів близько у 50\% випадків дотримувалася обмежень у вживанні вуглеводів, солі та щоденно споживали свіжі овочі та фрукти. Результати представлені в таблиці 1. 
Таблиця 1. Фактори ризику у паціснтів порівнюваних груп

\begin{tabular}{|c|c|c|c|c|c|c|}
\hline \multirow{3}{*}{ Кориговані фактори ризику } & \multicolumn{6}{|c|}{ Групи хворих } \\
\hline & \multicolumn{2}{|c|}{ I } & \multicolumn{2}{|c|}{ II } & \multicolumn{2}{|c|}{ III } \\
\hline & $\begin{array}{c}\text { Сільські } \\
\text { жителі }\end{array}$ & $\begin{array}{l}\text { Міські } \\
\text { жителі }\end{array}$ & $\begin{array}{c}\text { Сільські } \\
\text { жителі }\end{array}$ & $\begin{array}{l}\text { Міські } \\
\text { жителі }\end{array}$ & $\begin{array}{l}\text { Сільські } \\
\text { жителі }\end{array}$ & $\begin{array}{l}\text { Міські } \\
\text { жителі }\end{array}$ \\
\hline Вживання алкоголю (\%) & 38,9 & 62,5 & 38,2 & 41,2 & 11,8 & 37,5 \\
\hline Паління (\%) & 0 & 25 & 17,6 & 5,9 & 0 & 4,2 \\
\hline Надлишкова маса тіла (\%) & 16,7 & 29,2 & 26,5 & 44,1 & 17,6 & 29,2 \\
\hline Ожиріння (\%) & 77,8 & 45,8 & 61,8 & 44,1 & 23,5 & 62,5 \\
\hline $\begin{array}{l}\text { Низький рівень фізичної } \\
\text { активності (\%) }\end{array}$ & 29,9 & 39,2 & 31 & 44,2 & 30,1 & 57,9 \\
\hline Нездорове харчування (\%) & 100 & 91,7 & 88,2 & 85,3 & 23,5 & 54,2 \\
\hline
\end{tabular}

Аналіз отримуваної антигіпертензивної терапії даних пацієнтів показав, що найбільш вживаною групою препаратів були інгібітори ангіотензинперетворюючого ферменту та блоктори ангіотензинових рецепторів (сартани) (ці препарати в переважній більшості були призначені в складі комбінованих препаратів, до яких входив і діуретик). Наступними за частотою призначення були бета-адреноблокатори. Щодо жителів сільської місцевості, частіше прослідковувалось застосування антигіпертензивних препаратів центральної дії - 10,6\% та 4,7\% випадків відповідно. За ізольованого перебігу ГХ незалежно від територіальної приналежності, пацієнти досягали цільових рівнів АТ, використовуючи лише один комбінований препарат, у деяких випадках 2 препарати. Тоді як в разі коморбідного перебігу ГХ з IXC та ЦД 2 типу застосовувалось три а інколи і чотири таблетовані форми препаратів. Також у жителів міста третьої групи застосовувалась антигіпертензивна терапія із залученням всіх груп препаратів основної лінії в однаковій кількості, задля досягнення цільового рівня АТ, що говорить про більш стійкий перебіг ГХ у даної групи пацієнтів. Застосування трьох і більше таблетованих препаратів антигіпертензивної терапії зворотно корелювало із прихильністю до АГТ $(\mathrm{p}<0,05)$. Результати відображені в таблиці 2.

\section{Таблиця 2. Прихильність до лікування у сільських та міських жителів порівнюваних груп}

\begin{tabular}{|l|c|c|c|c|c|c|}
\hline \multirow{2}{*}{ Прихильність до лікування } & \multicolumn{3}{|c|}{ Групи хворих } \\
& \multicolumn{2}{|c|}{$\mathbf{I}$} & \multicolumn{2}{|c|}{ II } \\
\cline { 2 - 7 } & $\begin{array}{c}\text { Сільські } \\
\text { жителі }\end{array}$ & $\begin{array}{c}\text { Міські } \\
\text { жителі }\end{array}$ & $\begin{array}{c}\text { Сільські } \\
\text { жителі }\end{array}$ & $\begin{array}{c}\text { Міські } \\
\text { жителі }\end{array}$ & $\begin{array}{c}\text { Сільські } \\
\text { жителі }\end{array}$ & $\begin{array}{c}\text { Міські } \\
\text { жителі }\end{array}$ \\
\hline Висока & $2(11,1 \%)$ & $3(12,0 \%)$ & $5(14,7 \%)$ & $6(17,6 \%)$ & $1(7,1 \%)$ & $2(8,3 \%)$ \\
\hline Середня & $5(27,8 \%)$ & $5(20,0 \%)$ & $8(23,5 \%)$ & $9(26,5 \%)$ & $4(28,6 \%)$ & $3(12,5 \%)$ \\
\hline Низька & $11(61,1 \%)$ & $17(68,0 \%)$ & $21(61,8 \%)$ & $19(55,9 \%)$ & $9(64,3 \%)$ & $19(79,2 \%)$ \\
\hline
\end{tabular}

Перспективи подальшого розвитку в даному напрямку

Проведення подальших досліджень у зазначеному напрямку сприятиме розробці цілеспрямованих заходів профілактики артеріальної гіпертензії у різних вікових та гендерних групах, у міських та сільських жителів та на різних стадіях і ступенях артеріальної гіпертензії. Одночасно, результати досліджень сприятимуть оптимізації терапії та зменшенню кардіоваскулярного ризику у пацієнтів з артеріальною гіпертензією.

\section{Висновки}

У міських та сільських жителів виявлено достовірну різницю у переважанні впливу факторів ризику гіпертонічної хвороби на пацієнтів, як передумову виникнення i прогресування гіпертонічної хвороби. Інформованість сільських i міських жителів щодо несприятлитвого впливу факторів ризику як при ізольованому перебігу гіпертонічної хвороби, так і при іiі коморбідному перебігу формує прихильність до проведення лікувально-профілактичних заходів та тривалого прийому антигіпертензивних препаратів.

\section{Література}

1. Горбась І.М. Епідеміологічні та медико-соціальні аспекти артеріальної гіпертензії / І.М. Горбась // Укр. кардіол. журн. - 2010. - Додаток 1. - С. 16-21. 
2. Гулич М.П. Стратегія ВООЗ щодо профілактики неінфекційних захворювань та боротьби з ними: сучасні аспекти реалізації прогрсми CINDI в Україні / М.П. Гулич, А. В. Кобилянська // Environment \&Health. - 2010. - № 2. - С. $57-63$.

3. Драпкина О.М. Первый российский консенсус по количественной оценке приверженности к лечению: основные положения, алгоритмы и рекомендации / О.М. Драпкина., М.А. Ливзан, А.И. Мартынов и соавт. // Медицинский вестник Северного Кавказа. - 2018.-Т. 13. - № 1-2. - С.259-271 doi - https://doi.org/10.14300/mnnc.2018.13039.

4. Ждан В.М. Можливості й резерви діагностики, терапії та профілактики гіпертонічної хвороби в практиці сімейного лікаря на Полтавщині / В.М. Ждан, В.П. Лисак, І.П. Катеренчук, І.Ф. Шумейко, К.С. Вакуленко // Практикуючий лікар. - 2015. - № 2. - С. 25-28.

5. Николаев Н.А. Количественная оценка приверженности к лечению в клинической медицине: протокол, процедура, интерпретация / Н.А. Николаев, Ю.П. Скирденко, В.В. Жеребилов // Качественная клиническая практика. -2016. №1. - С. 50-59.

6. Поширеність факторів ризику серцево-судинних захворювань в Україні: сучасний погляд на проблему // Укр. кардіол. журн. - 2018. - Додаток 1. - С. 91-101.

7. Сіренко Ю.М. Результати тримісячного спостереження за лікуванням пацієнтів 3 артеріальною гіпертензією лікарями загальної практики в Україні (Програма «Можливості ефективного контролю артеріального тиску за допомогою вітчизняних ліків») / Ю.М. Сіренко, Г.Д. Радченко, І.М. Марцовенко від імені учасників дослідження // Артеріальна гіпертензія. - 2009. - № 4. - С. 3-14.

8. Слащева Т.Г.. Чинники, що асоціюються зі зміною прихильності пацієнта до антигіпертензивного лікування / Т.Г. Слащева, Г.Д. Радченко, Ю.М. Сіренко, І.М. Марцовенко // Український кардіологічний журнал. - 2017. - №5. - С. 29-39.

9. Morisky D.E. Concurrent and predictive validity of a self-reported measure of medication adherence / D.E. Morisky, L.W. Green, D.M. Levine// Med. Care. 1986; 24 (1): 67-74.

\section{References}

1. Horbas' I.M. Epidemiolohichni ta medyko-sotsial'ni aspekty arterial'noyi hipertenziyi / I.M. Horbas' // Ukr. kardiol. zhurn. - 2010. - Dodatok 1. - S. 16-21.

2. Hulych M.P. Stratehiya VOOZ shchodo profilaktyky neinfektsiynykh zakhvoryuvan' ta borot'by z nymy: suchasni aspekty realizatsiyi prohrsmy CINDI v Ukrayini / M.P. Hulych, A. V. Kobylyans'ka // Environment \&Health. - 2010. - № 2. - S. 57-63.

3. Drapkyna O.M. Pervyy rossyyskyy konsensus po kolychestvennoy otsenke pryverzhennosty k lechenyyu: osnovnye polozhenyya, alhorytmy y rekomendatsyy / O.M. Drapkyna., M.A. Lyvzan, A.Y. Martynov y soavt. // Medytsynskyy vestnyk Severnoho Kavkaza.- 2018.-T. 13. -№ 1-2.-S.259-271 doi - https://doi.org/10.14300/mnnc.2018.13039.

4. Zhdan V.M. Mozhlyvosti y rezervy diahnostyky, terapiyi ta profilaktyky hipertonichnoyi khvoroby v praktytsi simeynoho likarya na Poltavshchyni / V.M. Zhdan, V.P. Lysak, I.P. Katerenchuk, I.F. Shumeyko, K.YE. Vakulenko // Praktykuyuchyy likar. 2015. - № 2. - C. 25-28.

5. Nykolaev N.A. Kolychestvennaya otsenka pryverzhennosty k lechenyyu v klynycheskoy medytsyne: protokol, protsedura, ynterpretatsyya / N.A. Nykolaev, YU.P. Skyrdenko, V.V. Zherebylov // Kachestvennaya klynycheskaya praktyka. -2016. №1. - S. 50-59.

6. Poshyrenist' faktoriv ryzyku sertsevo-sudynnykh zakhvoryuvan' v Ukrayini: suchasnyy pohlyad na problemu // Ukr. kardiol. zhurn. - 2018. - Dodatok 1. - S. 91-101.

7. Sirenko YU.M. Rezul'taty trymisyachnoho sposterezhennya za likuvannyam patsiyentiv z arterial'noyu hipertenziyeyu likaryamy zahal'noyi praktyky v Ukrayini (Prohrama «Mozhlyvosti efektyvnoho kontrolyu arterial'noho tysku za dopomohoyu vitchyznyanykh likiv») / YU.M. Sirenko, H.D. Radchenko, I.M. Martsovenko vid imeni uchasnykiv doslidzhennya // Arterial'na hipertenziya. - 2009. - № 4. - S. 3-14.

8. Slashcheva T.H.. Chynnyky, shcho asotsiyuyut'sya zi zminoyu prykhyl'nosti patsiyenta do antyhipertenzyvnoho likuvannya / T.H. Slashcheva, H.D. Radchenko, YU.M. Sirenko, I.M. Martsovenko // Ukrayins'kyy kardiolohichnyy zhurnal. - 2017. №5. - S. 29-39.

9. Morisky D.E. Concurrent and predictive validity of a self-reported measure of medication adherence / D.E. Morisky, L.W. Green, D.M. Levine// Med. Care. 1986; 24 (1): 67-74.

Дата надходження рукопису до редакції: 04.03.2020 p.

Мета дослідження. Визначити значимість інформованості міських та сільських жителів про фактори ризику артеріальної гіпертензії та їх вплив на прихильність до лікувально-профілактичних заходів, а також визначити переважання факторів ризику розвитку та прогресування гіпертонічної хвороби в залежності від територіальної приналежності пацієнтів.

Матеріали та методи. Проаналізовано інформованість пацієнтів щодо основних коригованих факторів ризику виникнення та прогресування ГХ. Рівень прихильності до прийому антигіпертензивних препаратів було оцінено шляхом використання опитувальника Моріски-Грін. Аналіз ефективності антигіпертензивної терапії визначався шляхом досягнення цільових значень АТ для кожної з порівнюваних груп.

Результати. В залежності від територіальної приналежності виявлено достовірну різницю у переважанні впливу факторів ризику гіпертонічної хвороби на пацієнтів, як передумову виникнення і прогресування гіпертонічної хвороби. Встановлено статистично значущу залежність між територіальною приналежністю паціснтів та інформованістю щодо основних коригованих факторів ризику. Показано, що низька прихильність до лікувально-профілактичних заходів 
асоціювалася з недостатнім рівнем інформованості різних верств населення, наявністю коморбідного перебігу гіпертонічної хвороби та особливістю призначеної антигіпертензивної терапії.

Висновки. У міських та сільських жителів виявлено достовірну різницю у переважанні впливу факторів ризику гіпертонічної хвороби на пацієнтів, як передумову виникнення і прогресування гіпертонічної хвороби. Інформованість сільських і міських жителів щодо несприятливого впливу факторів ризику як при ізольованому перебігу гіпертонічної хвороби, так і при іiі коморбідному перебігу формує прихильність до проведення лікувально-профілактичних заходів та тривалого прийому антигіпертензивних препаратів.

Ключові слова: гіпертонічна хвороба, фактори ризику, прихильність до терапії.

Цель исследования. Определить значимость информированности городских и сельских жителей о факторах риска артериальной гипертензии и их влияние на приверженность лечебно-профилактических мероприятий, а также определить преобладание факторов риска развития и прогрессирования гипертонической болезни в зависимости от территориальной принадлежности пациентов.

Материалы и методы. Проанализированы информированность пациентов об основных корректируемых факторах риска возникновения и прогрессирования ГБ. Уровень приверженности к приему антигипертензивных препаратов был оценен путем использования опросника Мориски-Грин. Анализ эффективности антигипертензивной терапии определялся путем достижения целевых значений АД для каждой из сравниваемых групп.

Результаты. В зависимости от территориальной принадлежности выявлено достоверную разницу в преобладании влияния факторов риска гипертонической болезни на пациентов, как предпосылку возникновения и прогрессирования гипертонической болезни. Установлено статистически значимую зависимость между территориальной принадлежностью пациентов и информированностью об основных корректируемых факторах риска. Показано, что низкая приверженность лечебно-профилактических мероприятий ассоциировалась с недостаточным уровнем информированности различных слоев населения, наличием коморбидного течения гипертонической болезни и особенностью назначенной антигипертенгзивной терапии.

Выводы. В городских и сельских жителей обнаружено достоверную разницу в преобладании влияния факторов риска гипертонической болезни на пациентов, как предпосылку возникновения и прогрессирования заболевания. Информированность сельских и городских жителей по неблагоприятному воздействию факторов риска как при изолированном течении гипертонической болезни, так и при ее коморбидном течении формирует приверженность к проведению лечебно-профилактических мероприятий и длительному приему антигипертензивных препаратов.

Ключевые слова: гипертоническая болезнь, факторы риска, приверженность к терапии.

Aim of the study. To determine the importance of urban and rural populations awareness to the essential hypertension risk factors and their impact on the compliance to treatment and preventive measures, as well as to determine the prevalence of risk factors for the new-onset of arterial hypertension and its progression in dependence to the territorial affiliation of patients.

Materials and methods. The degree of patients' awareness about the main adjustable risk factors for the occurrence and progression of hypertension were analyzed. It was assessed using the Moriski-Green questionnaire. An analysis of the antihypertensive therapy effectiveness was based on the evaluation of the number of patients achieved target blood pressure values in each of the compared groups.

Results. Depending on the territorial affiliation, a significant difference was observed in the predominance of the hypertension adjustable risk factors between urban and rural populations, that was concerned as prerequisite for the occurrence and progression of hypertension. Statistically significant correlation was found between the territorial affiliation of patients and awareness to the main correctable risk factors. It was shown that low adherence to treatment and prophylactic measures was associated with an insufficient level of population awareness, as well, as with the presence of a hypertension comorbid clinical course and depending on prescribed antihypertensive therapy.

Conclusions. A significant difference was found in urban and rural populations in the predominance of the hypertension adjustable risk factors that is the prerequisition for the onset and progression of the disease. Awareness of rural and urban residents on the unfavourable effects of risk factors as in the form of the isolated course of hypertension and as in the form of comorbid course determines an adherence to the therapeutic and preventive measures and to the long-term use of antihypertensive drugs.

Keywords: hypertension, risk factors, adherence to the therapy.

Конфлікт інтересів: відсутній.

Conflicts of interest: authors have no conflicts of interest to declare.

\section{Відомості про авторів}

Черкун Маргарита Петрівна - аспірант кафедри внутрішньої медицини № 2 з професійними хворобами Української медичної стоматологічної академії; вул. Шевченка, 23, м. Полтава, 36024, Україна.

Катеренчук Іван Петрович - доктор медичних наук, професор, завідувач кафедри внутрішньої медицини № 2 3 професійними хворобами Української медичної стоматологічної академії; вул. Шевченка, 23, м. Полтава, 36024, Україна. ikaterenchuk@ukr.net. 